\title{
Source Fault Model of the 1771 Yaeyama Tsunami, Southern Ryukyu Islands, Japan, Inferred from Numerical Simulation
}

\author{
MAMORU NAKAMURA ${ }^{1}$
}

\begin{abstract}
The 1771 Yaeyama tsunami is successfully reproduced using a simple faulting model without submarine landslide. The Yaeyama tsunami (M 7.4), which struck the southern Ryukyu Islands of Japan, produced unusually high tsunami amplitudes on the southeastern coast of Ishigaki Island and caused significant damage, including 12,000 casualties. Previous tsunami source models for this event have included both seismological faults and submarine landslides. However, no evidence of landslides in the source has been obtained, despite marine surveying of the area. The seismological fault model proposed in this study, describing a fault to the east of Ishigaki Island, successfully reproduces the distribution of tsunami runup on the southern coast of the Ryukyu Islands. The unusual runup heights are found through the numerical simulation attributable to a concentration of tsunami energy toward the southeastern coast of Ishigaki Island by the effect of the shelf to the east. Thus, the unusual runup heights observed on the southeastern coast of Ishigaki Island can be adequately explained by a seismological fault model with wave-ray bending on the adjacent shelf.
\end{abstract}

Key words: The 1771 Yaeyama tsunami, Ryukyu Islands, tsunami generation.

\section{Introduction}

On April 24, 1771, a large earthquake (the Yaeyama earthquake tsunami, M 7.4) struck the southern Ryukyu Islands (Fig. 1). The main shock was widely felt throughout the Ryukyu Islands exceeding $350 \mathrm{~km}$ from the epicenter. Later large tsunami struck the same area, reaching a maximum height exceeding $30 \mathrm{~m}$ on the southeastern side of Ishigaki Island (Fig. 1) (NAKATA and Kawana, 1995). The damage area was distributed between Ishigaki Island and Miyako Island, resulting in significant damage and approximately 12,000 casualties.

The source area of the tsunami has been estimated, based on two documented observations, to have been to the southeast of Ishigaki Island (Fig. 1) (IMAMURA,

\footnotetext{
${ }^{1}$ Faculty of Science, University of the Ryukyus, Senbaru 1, Nishihara-cho, Okinawa, 9030213, Japan. (E-mail: mnaka@sci.u-ryukyu.ac.jp)
} 

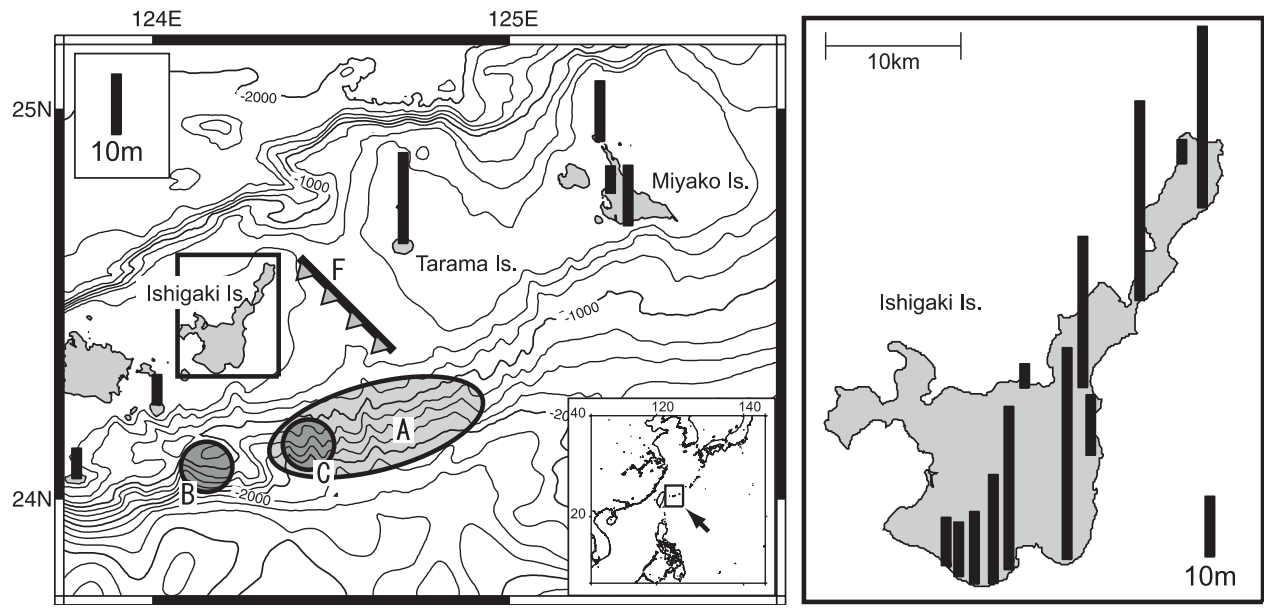

Figure 1

Map of the southern Ryukyu Islands. The large ellipsoid (A) denotes the source area of the Yaeyama tsunami as estimated in previous studies (HATORI, 1998; NAKATA and KAWANA, 1995). Hatched areas (B and $\mathrm{C}$ ) denote the locations of the submarine landslide estimated in marine surveys (MATSUMOTO and Kimura, 1993; MAтsumoto et al., 2001) and the previous tsunami simulations (ImAmurA et al., 2001), respectively. Bars indicate runup heights, and " $F$ " denotes the location of the fault to the east of Ishigaki

Island.

1938; HATORI, 1988). Waves of over $10 \mathrm{~m}$ were recorded on the southern coast between Ishigaki Island and Miyako Island, and the tsunami was reported to surge from the southeast to strike Ishigaki Island.

Numerous simulations have been conducted for this tsunami, and the source models employed can be broadly classified into seismological fault models (NAKATA and KawANA, 1995), submarine landslide models (HiYOshi et al., 1986), and faultand-landslide models (Hiraishi et al., 2001; ImAMURA et al., 2001). In the seismological fault model, the fault is set to the southeast of Ishigaki Island (area A in Fig. 1), and an earthquake magnitude of M 8 is assumed. However, this model predicts a maximum runup height of $10 \mathrm{~m}$ on the southeast of Ishigaki Island, which is smaller than the observed runup. The submarine landslide model assumes the occurrence of a landslide to the south of Ishigaki Island, and reproduces the runup height on the southeastern side of Ishigaki Island well, with the tsunami energy concentrated in that area. However, this model cannot successfully reproduce the runup height observed at Tarama and Miyako Islands. The fault-and-landslide model, on the other hand, describes both a seismological fault and a submarine landslide on the southern slope of Ishigaki Island (Fig. 1), and the model reproduces the runup height at all locations well.

The tsunami simulation using the fault-and-landslide model therefore suggests the occurrence of a submarine landslide to the southeast of Ishigaki Island (area $\mathrm{C}$ in Fig. 1). In order to verify whether this model is correct, marine surveys have been 
carried out to the south of Ishigaki Island, and depressions thought to represent landslides have been identified at $23^{\circ} 55^{\prime} \mathrm{N}-24^{\circ} 00^{\prime} \mathrm{N}$ and $124^{\circ} 10^{\prime} \mathrm{E}-124^{\circ} 20^{\prime} \mathrm{E}$ (area B) (Matsumoto and Kimura, 1993; Matsumoto et al., 2001). However, the timing of the landslide cannot be determined. Furthermore, although the simulation requires a submarine landslide in area $\mathrm{C}$, no evidence of landslides has yet been found in that area, nor has the fault in the source area.
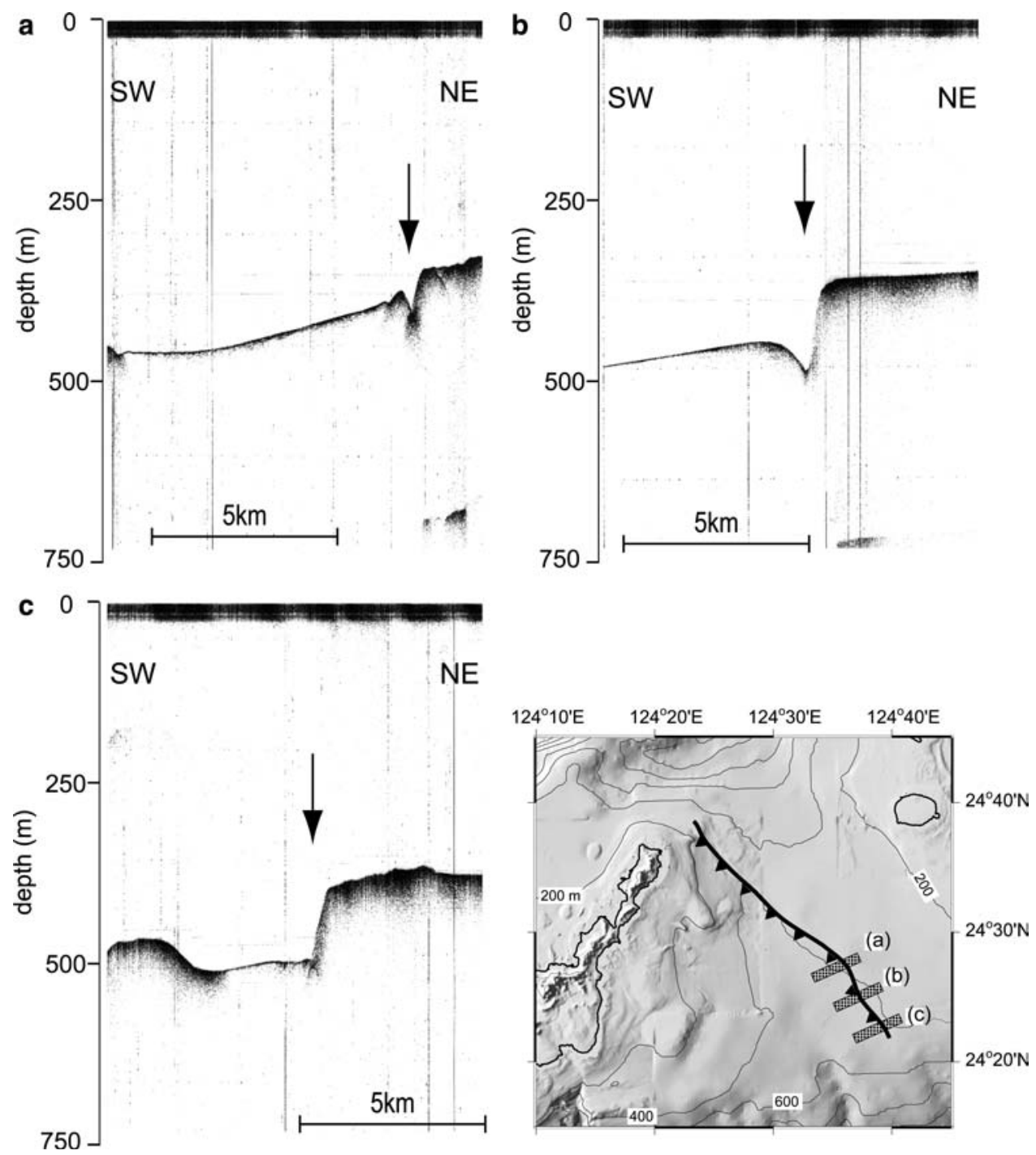

Figure 2

Profiles of $12 \mathrm{kHz}$ surveys conducted across the fault to the east of Ishigaki Island. Arrows denote the location of the fault. 
All previous studies have assumed that the tsunami originated on the south slope of Ishigaki Island. However, a remarkable NW-SE striking fault is located to the east of Ishigaki Island (HAMAмото et al., 1979; RESEARCH Group For Active FAults in JAPAN, 1991) (Fig. 2), extending for approximately $50 \mathrm{~km}$ with an average vertical slip of $50-100 \mathrm{~m}$ and dip toward the southwest (Fig. 2). As the direction of extensional stress and strain is parallel to the trench in the area of the southern Ryukyu Islands (Kubo and Fukuyama, 2003; NAKAmura, 2004), the slip of this fault is considered to represent normal faulting. Although the timing of the latest faulting has yet to be determined, the possibility of this fault as the source of the Yaeyama tsunami has not been discussed, despite being located near the anticipated source area. In the present study, the tsunami source is reconstructed by numerical analysis of wave propagation and application of the wave-ray method, and it is shown that the event can be successfully explained using only a fault model, without submarine faulting.

\section{Simulation Conditions}

The numerical simulation performed in this study, including runup along the coast based on shallow water theory, is compared to the recorded runup heights on the Islands coasts.

The tsunami propagation is computed using nonlinear shallow-water equations (e.g., Satake, 1995).

$$
\begin{gathered}
\frac{\partial \eta}{\partial t}+\frac{\partial M}{\partial x}+\frac{\partial N}{\partial y}=0 \\
\frac{\partial M}{\partial t}+\frac{\partial}{\partial x}\left(\frac{M^{2}}{D}\right)+\frac{\partial}{\partial y}\left(\frac{M N}{D}\right)+g D \frac{\partial \eta}{\partial x}+\frac{g n^{2}}{D^{7 / 3}} M \sqrt{M^{2}+N^{2}}=0 \\
\frac{\partial N}{\partial t}+\frac{\partial}{\partial x}\left(\frac{M N}{D}\right)+\frac{\partial}{\partial y}\left(\frac{N^{2}}{D}\right)+g D \frac{\partial \eta}{\partial y}+\frac{g n^{2}}{D^{7 / 3}} N \sqrt{M^{2}+N^{2}}=0
\end{gathered}
$$

where $(M, N)$ are discharge fluxes, $g$ is the gravitational acceleration, $h$ is water depth, $\eta$ the vertical displacement of the water surface above the water level, $D$ is the total water depth $(h+\eta)$, and $n$ is Manning's roughness coefficient $(n=0.025)$. The tsunami runup to land area is calculated based on the condition of IWASAKI and MANO (1979). The open boundary condition is used at the edge of the computational area.

The area for computation extended from $23^{\circ} 40^{\prime} \mathrm{N}$ to $25^{\circ} 30^{\prime} \mathrm{N}$, and from $123^{\circ} 40^{\prime} \mathrm{E}$ to $125^{\circ} 45^{\prime} \mathrm{E}$. The bathymetry and topography data were gridded at $75 \mathrm{~m}$ intervals over the entire area, and a finer grid interval of $25 \mathrm{~m}$ was employed for six areas for detailed analysis. The bathymetry data were provided by the Japan Ocean Data Center (JODC), and the topography data were provided by the Geographical 
Institute of Japan. The time interval for computation was $0.1 \mathrm{~s}$. The model was computed for a wave travel time of two hours.

Three source models were considered, F1, F2, and FL. Model F1 describes a reverse fault located to the southeast of Ishigaki Island (area A in the Fig. 1), corresponding to the source area estimated by previous studies (HATORI, 1988; NAKATA and KAWANA, 1995). The geometry of the fault was set as follows: $\phi=80^{\circ}$, $\delta=70^{\circ}, \lambda=90^{\circ}, L=66 \mathrm{~km}, W=33 \mathrm{~km}$, average slip of $8 \mathrm{~m}$, and seismic moment of $5.2 \times 10^{20} \mathrm{~N} / \mathrm{m}^{2}\left(\mathrm{M}_{\mathrm{w}}=7.8\right)$. The top edge of the fault was assumed to reach the ocean bottom. Ocean bottom displacement, assumed to be responsible for the initial water surface deformation giving rise to the tsunami, was computed using the dislocation formula provided by OKADA (1985).

Model F2 describes a normal fault located to the east of Ishigaki Island (Fig. 2), corresponding to the region of E-W extensional stress and strain in the south of Ryukyu arc (Kubo and FuKUYAMA, 2003; NAKAMURA, 2004). The fault geometry was set as follows: $\phi=135^{\circ}, \delta=70^{\circ}, \lambda=270^{\circ}, L=50 \mathrm{~km}, W=25 \mathrm{~km}$, average slip of $8 \mathrm{~m}$, and seismic moment of $3.0 \times 10^{20} \mathrm{~N} / \mathrm{m}^{2}(\mathrm{Mw}=7.6)$. The top edge of the fault was assumed to reach the ocean bottom, and ocean bottom displacement was computed using the dislocation formula provided by OKADA (1985).

Model FL describes both a seismological reverse fault (F1) and a submarine landslide on the southern slope of Ishigaki Island (area B in the Fig. 1). The location of the landslide is based on the results of the marine survey (MATSUMOTO and Kimura, 1993; Matsumoto et al., 2001). The dimensions of the landslide, $L=3 \mathrm{~km}$ and $W=2 \mathrm{~km}$, were estimated from the bathymetry data (Fig. 1), and the thickness of submarine landslide was set at $T=300 \mathrm{~m}$. The water depth was set at $d=1400 \mathrm{~m}$ at this location, with a slope of $\theta=25^{\circ}$. Static water-surface deformation estimated by an empirical formula derived by Grilli and Watts (1999) was employed, with a maximum ocean bottom displacement of $\eta_{\max }=52 \mathrm{~m}$.

\section{Results and Discussion}

\subsection{Comparison with Tsunami Heights}

Figure 3 shows a comparison between records and the results of the F1 model. The computed tsunami runup heights are less than $18 \mathrm{~m}$, significant by smaller than the observed heights, and the maximum simulated runup height which occurred on the north coast of Ishigaki Island. The runup height on the southeastern coast of Ishigaki Island, $9 \mathrm{~m}$, is one quarter of the observed runup. The geometric mean $(K)$ and index of scatter $(k)$ for this comparison (AIDA, 1978) were 1.78 and 1.64, respectively, suggesting that the computed heights are on average about one half of the observed values. Thus, the tsunami simulated using the F1 model does not successfully reproduce the unusual height distribution on the southeastern coast of Ishigaki Island. 

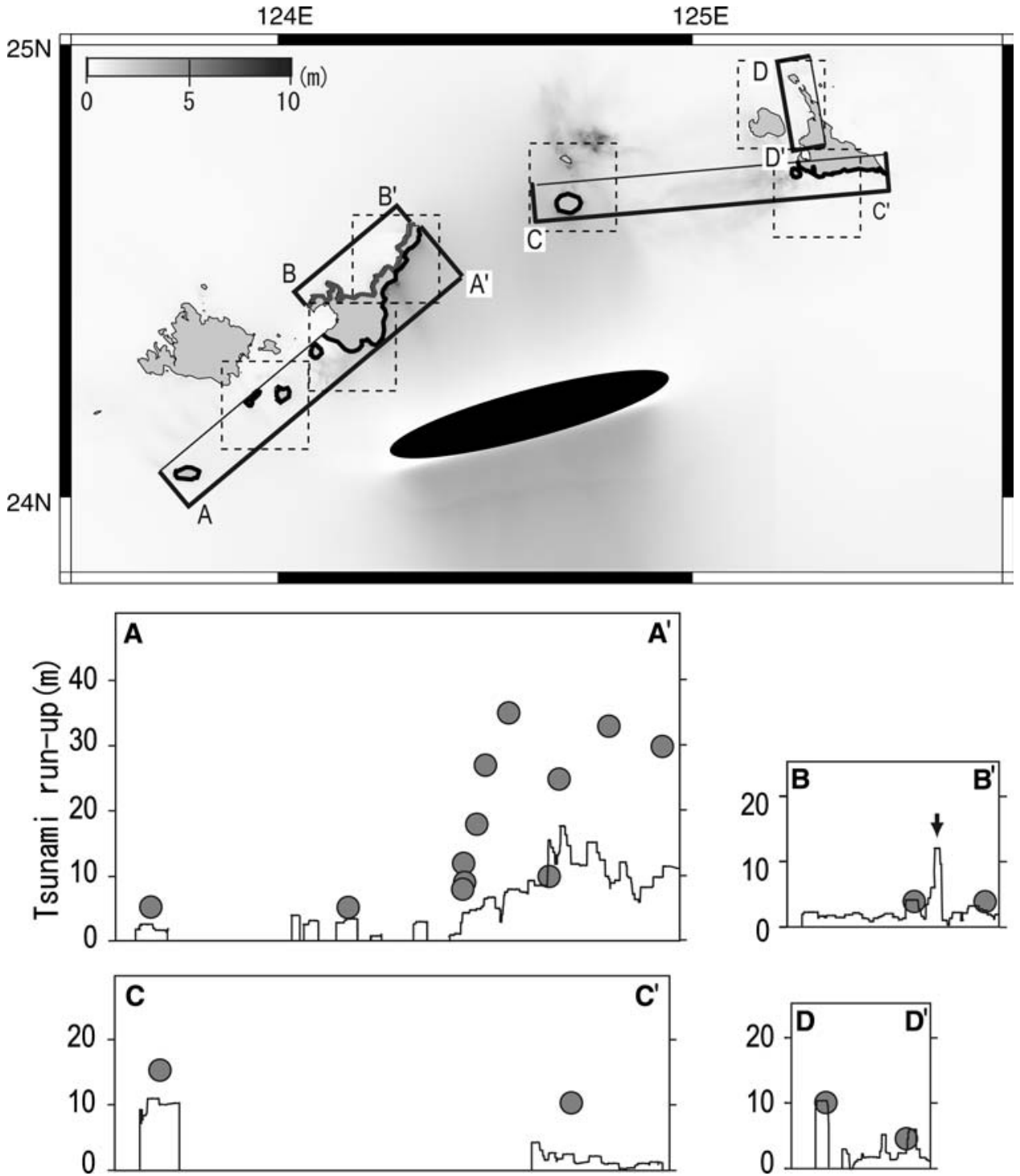

Figure 3

Results of tsunami computations for model F1. (Top) Spatial distribution of simulated maximum water level. Broken rectangles denote the areas gridded at $25 \mathrm{~m}$ intervals. (Bottom) Profile of simulated runup heights along the coast. Circles denote field-measured runup heights, and arrows delineate where the tsunami overtopped the island from the south coast to reach the north coast.

Figure 4 illustrates a comparison for model F2. The computed tsunami heights reproduce the unusual tsunami heights on the southeastern coast of Ishigaki Island well, reaching a maximum of $45 \mathrm{~m}$. However, the computed tsunami height is half of the observed height on the southern coast of Miyako Island. Nevertheless, the 

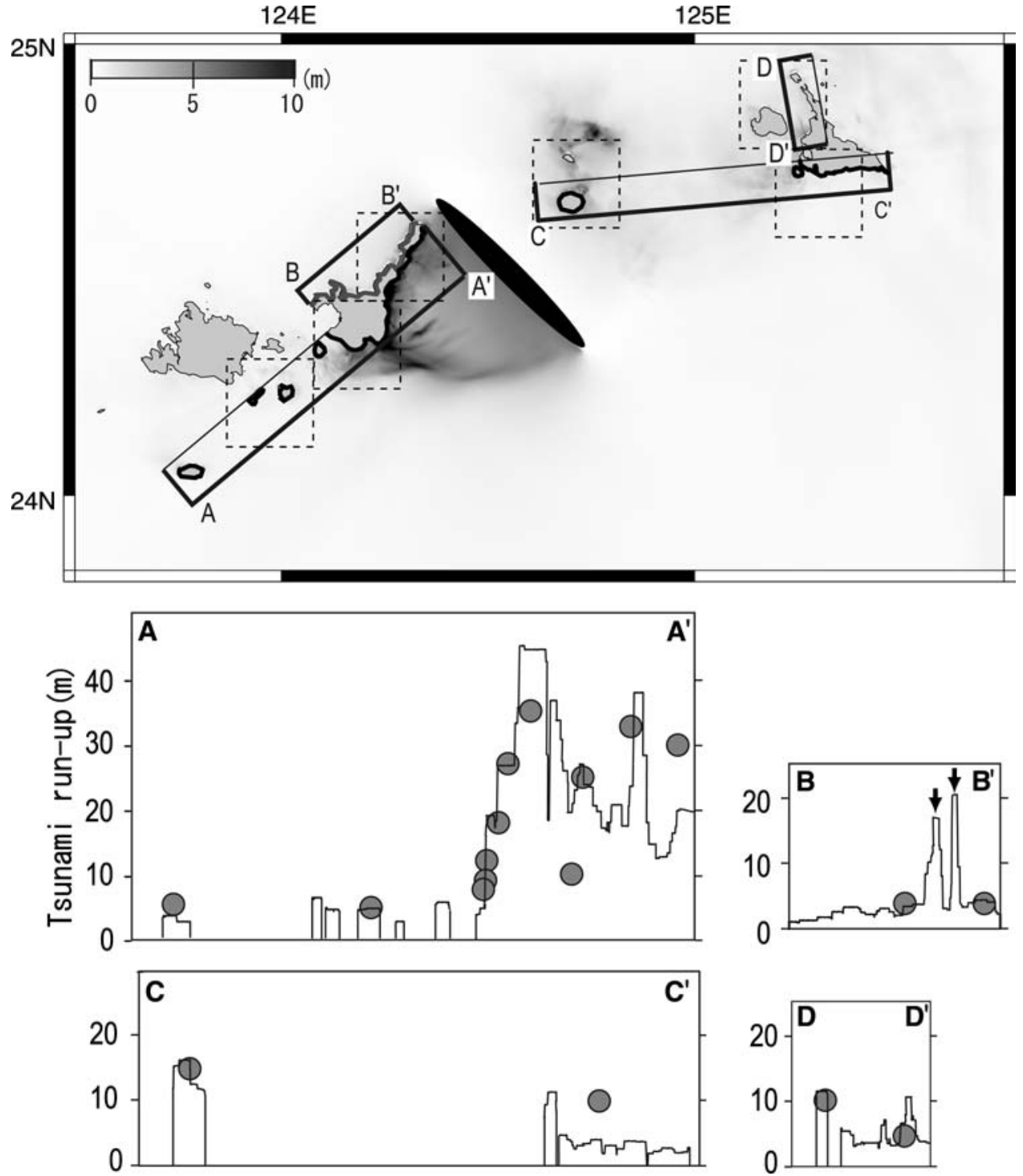

Figure 4

Results of tsunami computations for model F2. (Top) Spatial distribution of simulated maximum water level. Broken rectangles denote the areas gridded at $25 \mathrm{~m}$ intervals. (Bottom) Profile of simulated runup heights along the coast. Circles denote field-measured runup heights, and arrows demarcate where the tsunami overtopped the island from the south to reach the north coast.

tsunami heights computed using model F2 are closer to the observed heights compared to model F1. The $K$ and $k$ values for this comparison are 1.02 and 1.31 , respectively, suggesting that the computed heights are similar to the observed values. 

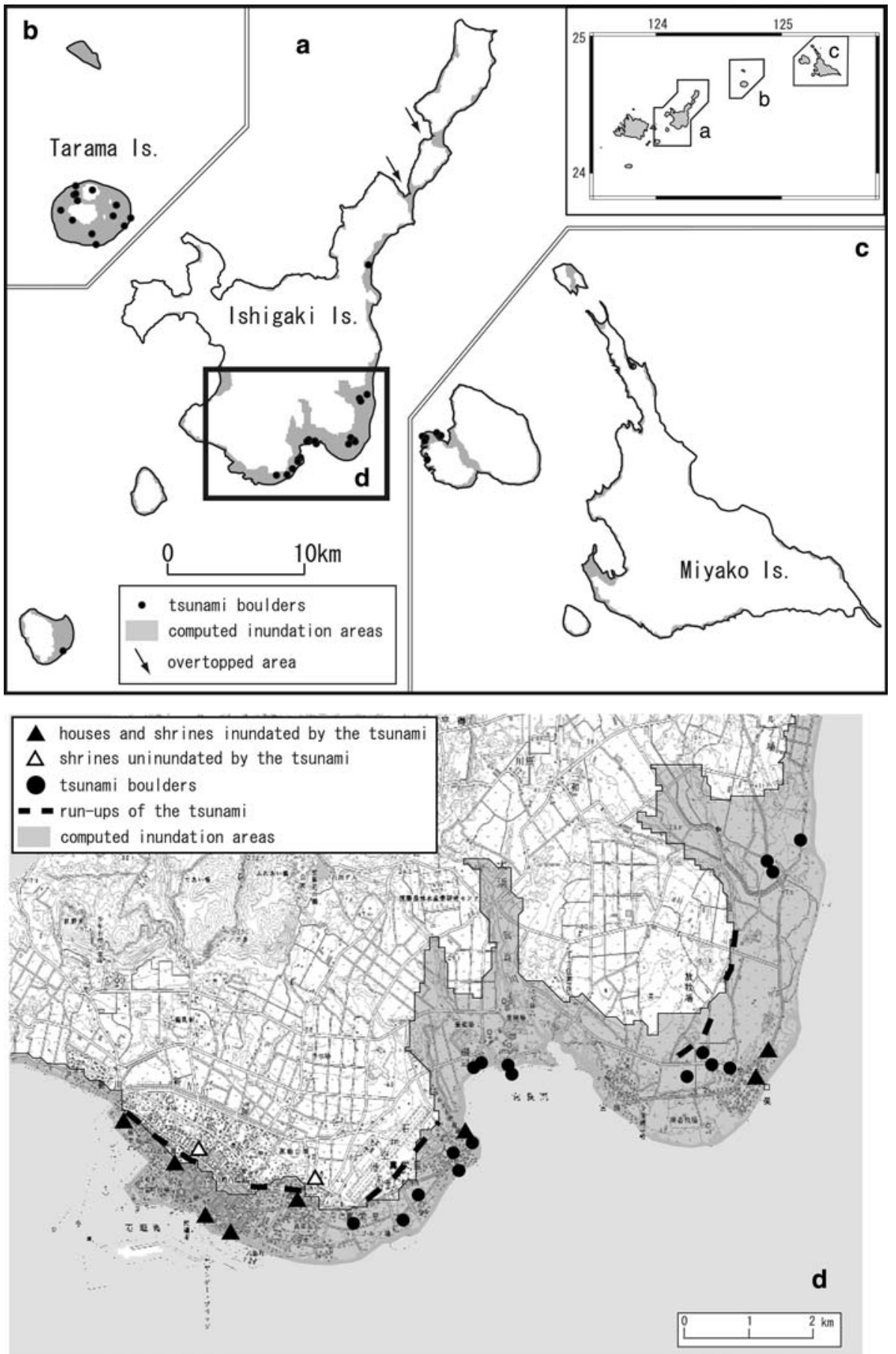
The tsunami inundation area, which is obtained through the model F2, is widely distributed at Tarama Island and south of Ishigaki Island (Fig. 5). This corresponds to the distribution of tsunami boulders, which were carried by the Yaeyama tsunami or prehistorical tsunamis (KATO et al., 1988; NAKATA and KawANA, 1995). The computed inundation area corresponds to the recorded one which is traced using the historical record, tsunami boulders, and damaged shrines at the south of Ishigaki Island. The runup heights of the observed tsunami were between $10 \mathrm{~m}$ and $30 \mathrm{~m}$ at the south of Ishigaki Island. The tsunami boulders and damaged shrines are located in the computed inundation area (Fig. 5). The undamaged shrines are located out of the computed inundation area.

Figure 6 presents the comparison for model FL. The $K$ and $k$ values for this comparison are 1.21 and 1.90 , respectively. The maximum runup height $(15 \mathrm{~m})$ occurs locally on the southwest coast of Ishigaki Island, which is induced by the concentration of tsunami energy at the southwest of Ishigaki Island (Fig. 6). Although the landslide model can generate maximum runup height locally, it cannot reproduce the runup height distribution. Thus the landslide model south of Ishigaki Island cannot reproduce the recorded maximum runup height distribution.

The average runup heights at F1, F2 and FL are $5 \mathrm{~m}$ or less on the north side of Ishigaki Island, but reach over $10 \mathrm{~m}$ locally (sections B-B', Figs. 3, 4, and 6). Distribution of the computed inundation area shows that the tsunami overtopped the island locally in the northeast of Ishigaki Island (top of Fig. 5). The northeast of Ishigaki Island consists of land-tied islands where islands are connected by sand spits (less than $10 \mathrm{~m}$ in elevation above sea level). The tsunami overtopped the sand spits and surged to the northwestern coast in the northeast of Ishigaki Island. This is consistent with the record that the village (10 $\mathrm{m}$ in elevation above sea level) on the sand spit at the northeast of Ishigaki Island was destroyed by the tsunami.

\subsection{Unusual Runup on the Southeastern Coast of Ishigaki Island}

Figure 7 shows the concentration of tsunami energy on the southeastern coast of Ishigaki Island, as determined by the wave-ray method using an ellipsoidal source and bathymetry data. In the case of model F2, the concentration of energy on the southeast coast of Ishigaki Island is induced by refraction at the shelf to the east. The

Figure 5

(Top) Tsunami inundated area computed by using the model F2. Solid circles show the tsunami boulders (KATO et al., 1988; Kawana and NAKATA, 1994; NAKATA and Kawana, 1995). Arrows signify where the tsunami overtopped the island from the south to reach the north coast. (Bottom) Tsunami inundation area and damages on the south of Ishigaki Island. Hatched depicts the inundated area computed by using the model F2. Solid and open triangles represent the shrines inundated and uninundated by the tsunami, respectively. Solid circles show the tsunami boulders (KATO et al., 1987; Kato 1988; NAKATA and KaWANa, 1995). Dashed lines denote the limit of observed inundation of the tsunami (KATO et al., 1987; 

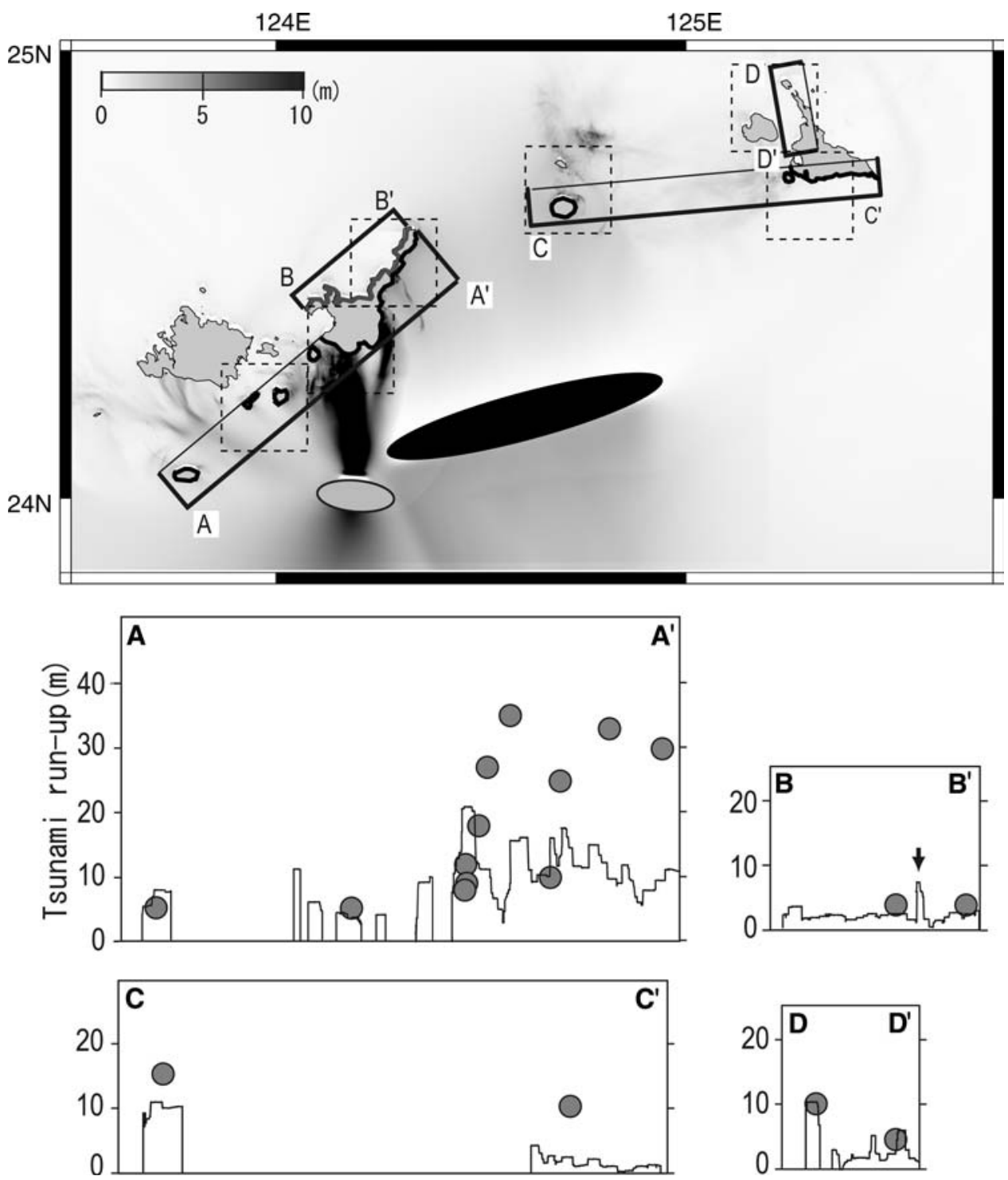

Figure 6

Results of tsunami computations for model FL. (Top) Spatial distribution of simulated maximum water level. Broken rectangles denote the areas gridded at $25 \mathrm{~m}$ intervals. (Bottom) Profile of simulated runup heights along the coast. Circles denote field-measured runup heights, and arrows indicate where the tsunami overtopped the island from the south to reach the north coast.

wave rays also bend on the southern slope, reinforcing the energy concentration on the southeastern coast of Ishigaki Island. This suggests that the effect of the shelf contributed strongly to the focusing of the tsunami toward the southeastern coast of 

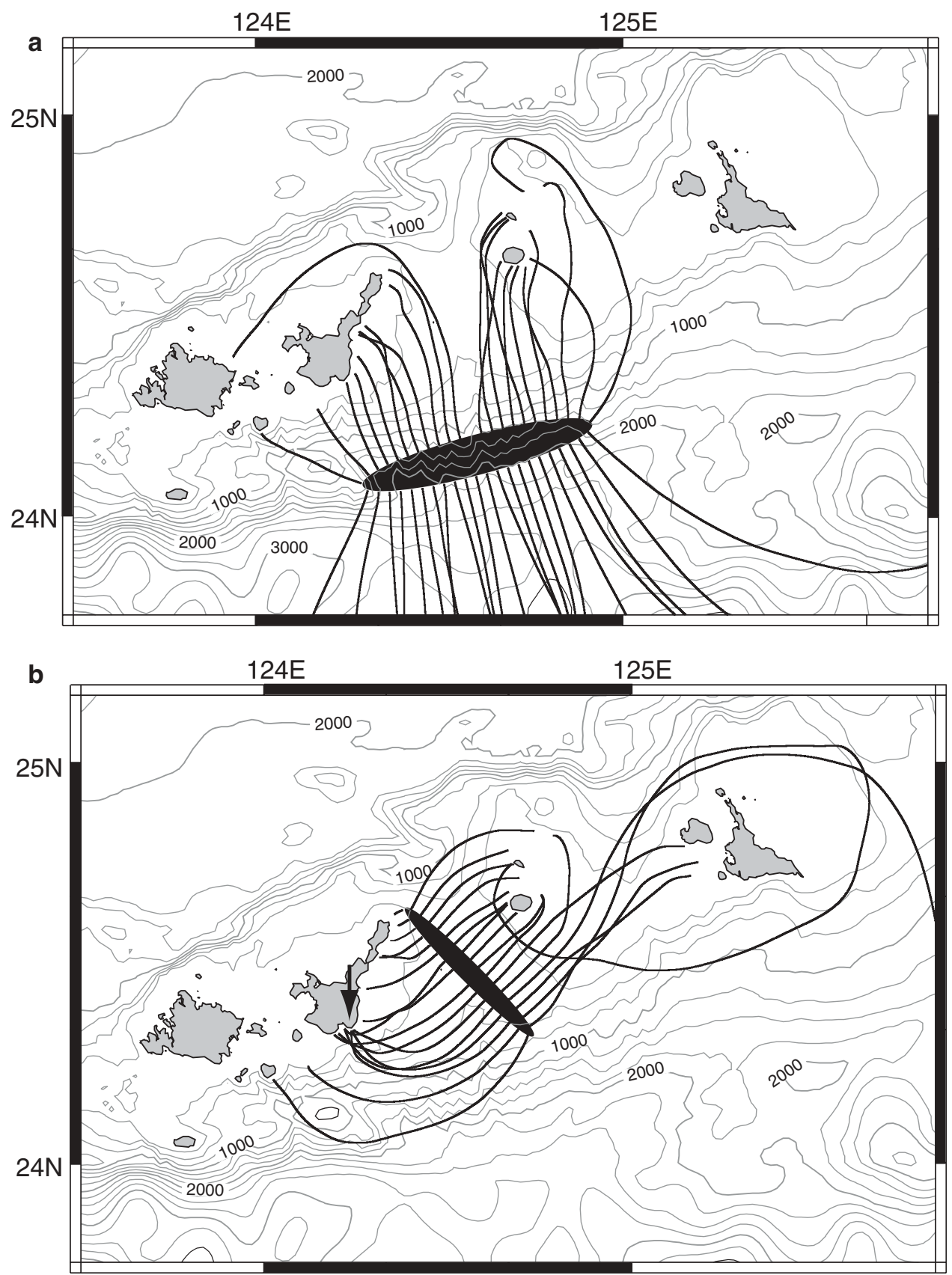

Figure 7

Pattern of energy radiation from ellipsoidal sources using the wave-ray method (upper: F1; lower: F2). 
Ishigaki Island. In the case of model F1, however, the energy concentration on the southeastern coast of Ishigaki Island is weak. Consequently, the effect of energy concentration is strongest for the case of a tsunami originating to the east of Ishigaki Island. This result suggests that the unusual tsunami runup of the Yaeyama tsunami is due largely to the concentration of energy by the shelf and not the result of a submarine landslide.

\subsection{Comparison of Seismic Intensity Distribution}

The main shock was felt over a distance of $350 \mathrm{~km}$ from the epicenter. The computed peak ground acceleration for the proposed fault model (F2) using the attenuation relationship (SI and MidorikAWA, 1999) is $10 \mathrm{~cm} / \mathrm{s}^{2}$ (Japan Meteorological Agency (JMA) intensity of 2) at the epicentral distance of $350 \mathrm{~km}$. This is consistent with the record that the earthquake was felt at the distance of $350 \mathrm{~km}$.

However, the earthquake damage to the houses has not been recorded although the tsunami devastation had been recorded at all villages. The computed peak ground acceleration for the model F2 is $250 \mathrm{~cm} / \mathrm{s}^{2}$ (JMA intensity of 5-) and $450-750 \mathrm{~cm} / \mathrm{s}^{2}$ (JMA intensity range of $5+$ and $6-$ ) at Miyako Island and Ishigaki Island, respectively. This would have caused the damage in the Ishigaki Island.

The missing records for the shaking damages might have been generated by the serious tsunami damage; the earthquake damage would have been obscured by the tsunami. All villages were distributed close to the shore at the Ishigaki Island to reduce the risk of malaria epidemics. Therefore the tsunami attacked all the villages after the earthquake, and caused serious damage to the villages. Since the tsunami washed away the damaged and undamaged houses after the earthquake, these might have been only recorded as the tsunami damage.

\section{Conclusions}

Simulations revealed that a normal-fault earthquake $\left(\mathrm{M}_{\mathrm{w}}\right.$ 7.6) to the east of Ishigaki Island is the most likely source of the 1771 Yaeyama tsunami. The model successfully reproduces the concentration of the tsunami energy on the southeastern coast of Ishigaki Island, and indicates that the unusual runup height on the southeastern coast was caused by energy concentration on the shelf to the east. Thus, the unusual runup heights can be explained by a model of seismological faulting without a submarine landslide. 


\section{Acknowledgements}

The author thanks the crew of the T/S Nagasaki-Maru, Nagasaki University, for the $12 \mathrm{kHz}$ survey, and the Japan Ocean Data Center for bathymetry data. Review by K. Satake improved the manuscript considerably.

\section{REFERENCES}

AIDA, I. (1978), Reliability of a Tsunami source model derived from fault parameters, J. Phys. Earth 26, $57-73$.

Grilli, S. T. and Watts, P. (1999), Modeling of waves generated by a moving submaerged body. Applications to underwater landslides, Engin. Analysis with Boundary Elements 23, 645-656.

Hamamoto, F., Sakurai, M., and Nagano, M. (1979), Submarine geology off the Miyako and Yaeyama Islands, Rep. Hydro. Ocean. Res, 14, 1-38 (in Japanese with English abst.).

Hatori, T. (1988), Tsunami magnitudes and source areas along the Ryukyu Islands, Zisin 41, $541-547$ (in Japanese with English abst.).

Hiraishi, T., Shibaki, H., and Hara, N. (2001), Numerical simulation of Meiwa-Yaeyama Earthquake Tsunami in landslide model with circular rupture, Pro. Coastal Engin, Japan Society Civil Engineering 48, 351-355 (in Japanese).

Hiyoshi, Y., Ando, M., and Kimura, M. (1986), Generation mechanism of the 1771 Nanseishoto Great Tsunami-generation of a large-scale underwater landslide, Abstract Volume of the Fall Meeting of the Seismological Society of Japan, pp. 80-80 (in Japanese).

Imamura, A. (1938), On the earthquakes zone of the Ryukyus and large Meiwa Tsunami, Zisin 10, 431-450 (in japanese).

Imamura, F., Yoshida, I., and Moore, A. (2001), Numerical study on the 1771 Meiwa Tsunami at Ishigaki Is., Okinawa and the Movement of the Tsunami Stones, Pro Coastal Engin., Japan Society Civil Engineering 48, 346-350 (in Japanese).

IWASAKI, T., and MANO, A. (1979), Two-dimensional numerical simulation of tsunami run-ups in the Eulerian description. Proc. $26^{\text {th }}$ Conference Coast. Eng., JSCE, 70-74 (in Japanese).

Kato, Y. (1987), Run-up height of Yaeyama seismic tsunami (1771), Zisin (J. Seism. Soc. Japan) 2, 40, 377-381.

Kato Y., Hidaka K., Kawano Y., and Shinjo R. (1988), Yaeyama Seismic Tsunami (1771) at Tarama Island, the Ryukyu Islands 1. Movement of reef blocks and a run-up height, Earth Science, JAGCJ 42, 84-90.

Kawana, T. and Nakata, T. (1994), Timing of late Holocene tsunamis originated around the southern Ryukyu islands, Japan, deduced from coralline tsunami deposits, J. Geography 103, 352-376 (in Japanese with English abst.).

Kubo, A. and Fukuyama, E. (2003), Stress field along the Ryukyu Arc and the Okinawa Trough inferred from moment tensors of shallow earthquakes, Earth Planet. Sci. Lett. 210, 305-316.

Matsumoto, T. and Kimura, M. (1993) Detailed bathymetric survey in the sea region of the estimated source area of 1771 Yaeyama earthquake tsunami and consideration of the mechanism of its occurrence, Zisin 45, 417-426 (in Japanese with English abst.).

Matsumoto, T., Kimura, M., NAKAmura, M. and Ono T. (2001), Large-scale slope failure and active erosion occurring in the southwest Ryukyu fore-arc area, Natural Hazards and Earth System Sciences 1, 203-211.

Nakamura, M. (2004), Crustal deformation in the central and southern Ryukyu Arc estimated from GPS data, Earth Planet. Sci. Lett. 217, 389-398.

Nakata, T., and Kawana, T., Historical and prehistorical large tsunamis in the southern Ryukyus, Japan, In Tsunami: Progress in Prediction, Disaster Prevention and Warning (eds. Y. Tsuchiya and N. Shuto) (Kluwer Academic Publishers 1995) pp. 211-222. 
OKadA, Y. (1985), Surface deformation due to shear and tensile faults in a half-space, Bull. Seismol. Soc. Am. 75, 1135-1154.

Research Group for Active Faults in Japan, Active Faults in Japan: Sheet Maps and Inventories (Tokyo Univ. Press., Tokyo 1991).

SATAKE, K. (1995), Linear and nonlinear computations of the 1992 Nicaragua earthquake tsunami, Pure Appl. Geophys. 144, 455-470.

Si, H. and MidorikawA, S. (1999), New attenuation relationships for peak ground acceleration and velocity considering effects of fault type and site condition, J. Struct. Const. Eng. AIJ 523, 63-70 (in Japanese).

(Received January 4, 2005; accepted April 17, 2005)

$$
\begin{aligned}
& \text { To access this journal online: } \\
& \text { http://www.birkhauser.ch }
\end{aligned}
$$

